Article

\title{
Estimation of the Impact of Ozone on Four Economically Important Crops in the City Belt of Central Mexico
}

 \\ Gema Luz Andraca-Ayala ${ }^{1}$, Ricardo Torres-Jardón ${ }^{1}$, José Santos García-Yee ${ }^{2}$, \\ Hugo Alberto Barrera-Huertas ${ }^{2}$, Arturo Gavilán-García ${ }^{3}$ and Roberto Basaldud Cruz ${ }^{3}$ \\ 1 Centro de Ciencias de la Atmósfera, Universidad Nacional Autónoma de México, \\ Circuito de la Investigación Científica s/n, Ciudad Universitaria, Ciudad de México 04510, \\ Mexico; bemar@unam.mx (B.E.M.-M.); agustin@atmosfera.unam.mx (J.A.G.-R.); \\ gema@atmosfera.unam.mx (G.L.A.-A.); rtorres@unam.mx (R.T.-J.) \\ 2 Programa de Posgrado en Ciencias de la Tierra. Unidad de Posgrado, edificio D, 1er piso. Circuito de \\ Posgrados, Ciudad Universitaria. Delegación Coyoacán, Ciudad de México C.P. 04510, Mexico; \\ jsgyee@gmail.com (J.S.G.-Y.); hbarrera@atmosfera.unam.mx (H.A.B.-H.) \\ 3 Instituto Nacional de Ecología y Cambio Climático (INECC), Blvd. Adolfo Ruíz Cortines 4209, \\ Jardines en la Montaña, Delegación Tlalpan, Ciudad de México C.P. 14210, Mexico; \\ arturo.gavilan@inecc.gob.mx (A.G.-G.); roberto.basaldud@inecc.gob.mx (R.B.C.) \\ * Correspondence: ruizs@unam.mx; Tel.: +52-55-5622-4073
}

Received: 18 January 2018; Accepted: 20 April 2018; Published: 11 June 2018

\begin{abstract}
In this work, we report the economic impact of exposure to high ozone concentrations on four important crops in the area of influence of the Mexico City Megalopolis. Estimated yield losses were as follows: maize: $3 \%$; oats: $26 \%$; beans: $14 \%$; sorghum: $15 \%$. The information needed to estimate the impact of air pollution in Mexico is decidedly deficient. Regarding ozone, the coverage provided by the monitoring networks is strongly focused on urban monitoring and its consistency over time is highly irregular. Apart from the Mexico City Metropolitan Area (MCMA) and less than a handful of other cities, the quality of the data is poor. Ozone in rural areas can be estimated with air quality models. However, these models depend on a high-resolution emissions inventory, which has only been done through validation processes in the MCMA. With these limitations, we set out to estimate the economic impact of exposure to ozone in these crops with a varying degree of sensitivity to ozone in the city belt of Central Mexico. To this end, we developed a procedure that makes optimal use of the sparse information available for construction of AOT40 (accumulated exposure over the threshold of $40 \mathrm{ppb}$ ) exceedance maps for the 2011 growing season. We believe that, due to the way in which we dealt with the sparse information and the uncertainty regarding the available data, our findings lie on the safe side of having little knowledge such that they may be useful to decision-makers. We believe that this procedure can be extended to the rest of the country, and that it may be useful to developing countries with similar monitoring and modeling capacities. In addition, these impacts are not evenly distributed in the region and sometimes they were greater in municipalities that have a higher index of poverty. Air pollution arriving from urban areas increases the social inequalities to which these already vulnerable populations are exposed.
\end{abstract}

Keywords: Mexico air quality; crops; ozone impact; exposure; AOT40

\section{Introduction}

Ozone is a delocalized free radical with high oxidant potential. In the troposphere it is formed by the photolysis of $\mathrm{NO}_{2}$ and by lightning [1]. Subsequent titration with $\mathrm{NO}$ yields a steady state driven 
by UV irradiance. In the presence of VOCs, the peroxy radicals $\left(\mathrm{RO}_{2}{ }^{\bullet}\right)$, formed during their photo degradation, oxidize $\mathrm{NO}$, opening a reaction path to $\mathrm{NO}_{2}$ without consuming $\mathrm{O}_{3}$, thus allowing its accumulation. In urban areas VOC and $\mathrm{NO}_{x}$ emissions enhance these processes, both formation and titration of $\mathrm{O}_{3}$. There, $\mathrm{O}_{3}$ production is generally VOC-limited. In rural and periurban areas with lower $\mathrm{NO}_{x}$ levels, $\mathrm{O}_{3}$ production is $\mathrm{NO}_{x}$-limited [2]. Increased ozone production occurs during times of high temperature and solar radiation, such as the stagnant high pressure systems in the spring and summer [3]. The different spatial distributions of $\mathrm{NO}_{x}$ and VOC production as well as $\mathrm{NO}$ destruction of ozone often result in higher ozone concentrations downwind of urban areas, rather than in the urban areas themselves, where they hinder plant growth [4,5]. Ozone can also be brought into a region by long range transport or by stratosphere-troposphere exchange [6].

Plants exposed to $\mathrm{O}_{3}$ show a reduction in growth $[7,8]$, which in commercial crops means lesser yield and revenue. In the year 2000, economic losses attributed to the worldwide adverse effect of ground-level ozone on maize, soybean, and wheat were estimated at \$11-18 billion USD [9].

One of the exposure indexes most closely associated with the injury observed in vegetation is the AOT40 cumulative exposure (accumulated exposure over the threshold of $40 \mathrm{ppb}$ ) index. This is calculated as the sum of the differences between the hourly mean ozone concentration and $40 \mathrm{ppb}$ when the concentration exceeds $40 \mathrm{ppb}$ during daylight hours. This value accumulates during periods of time that are defined based on the types of vegetation: usually three months for crops [10]. The exposure-response functions for the AOT40 index were derived from studies conducted under experimental conditions in which environmental conditions favoring the development of the plant and the maximum absorption of the pollutant were ensured [11].

There are also dose-response functions, which indicate the response of the plant to the dose of ozone absorbed using the calculation of ozone flow rates from the air to the plant [12]. By analogy with the exposure-response functions, a flow rate index for ozone accumulated during the plant's growth period is used. This flow rate is obtained by adding the hourly ozone flow rates over a given growth period that is defined depending on the type of vegetation. The calculation of the ozone flow rate takes into account the ambient ozone concentration and stomatal conductance [13]. Dose-exposure functions are easier to use and are more widely used [2,14].

Geographic information systems (GISs) can be used in order to estimate the economic impact of ozone on crops $[15,16] . \mathrm{O}_{3}$ maps consistent with the chosen function are made and overlaid on crop maps in order to apply those functions [15-17]. However, worldwide, there are much fewer rural ozone monitoring networks than urban ozone monitoring networks. Ozone monitoring networks are usually established in cities in order to protect the health of the population. This deficiency is even more visible in developing countries. As of 2011, in Mexico, there was not a single continuous air quality monitoring station specifically devoted to rural monitoring, and in the city belt of Central Mexico, there were three air quality monitoring systems (AQMSs) reporting ozone records from 36 monitoring stations to the "Sistema Nacional de Indicadores de Calidad del Aire" (SINAICA) (National Air Quality Information System) [18], not all of which have the same quality standards as the Mexico City Metropolitan Area (MCMA) network [19]. The data thus obtained are not sufficient to create exceedance maps for the critical value AOT40 in the region. It is well established that ozone concentration increases downwind of urban areas due to the absence of fresh of $\mathrm{NO}_{x}$ emissions, from which $\mathrm{NO}$ can titrate $\mathrm{O}_{3}$ [20]. Creating maps by interpolating only data from urban stations implies underestimation of the concentrations over all the rural areas in the city belt. Correlations between urban and rural sites [21] cannot be obtained in the complete absence of rural sites. The orographic barriers that separate the air basins in the center of the country impose further restrictions on the interpolation methods, when only using data from the available monitoring stations. Figure 1 shows how the monitoring stations (empty white circles) cluster in three groups. The largest group at the center corresponds to the MCMA, the cluster to the west corresponds to the Toluca Metropolitan Area, and the group located towards the east corresponds to the Puebla Metropolitan Area. 


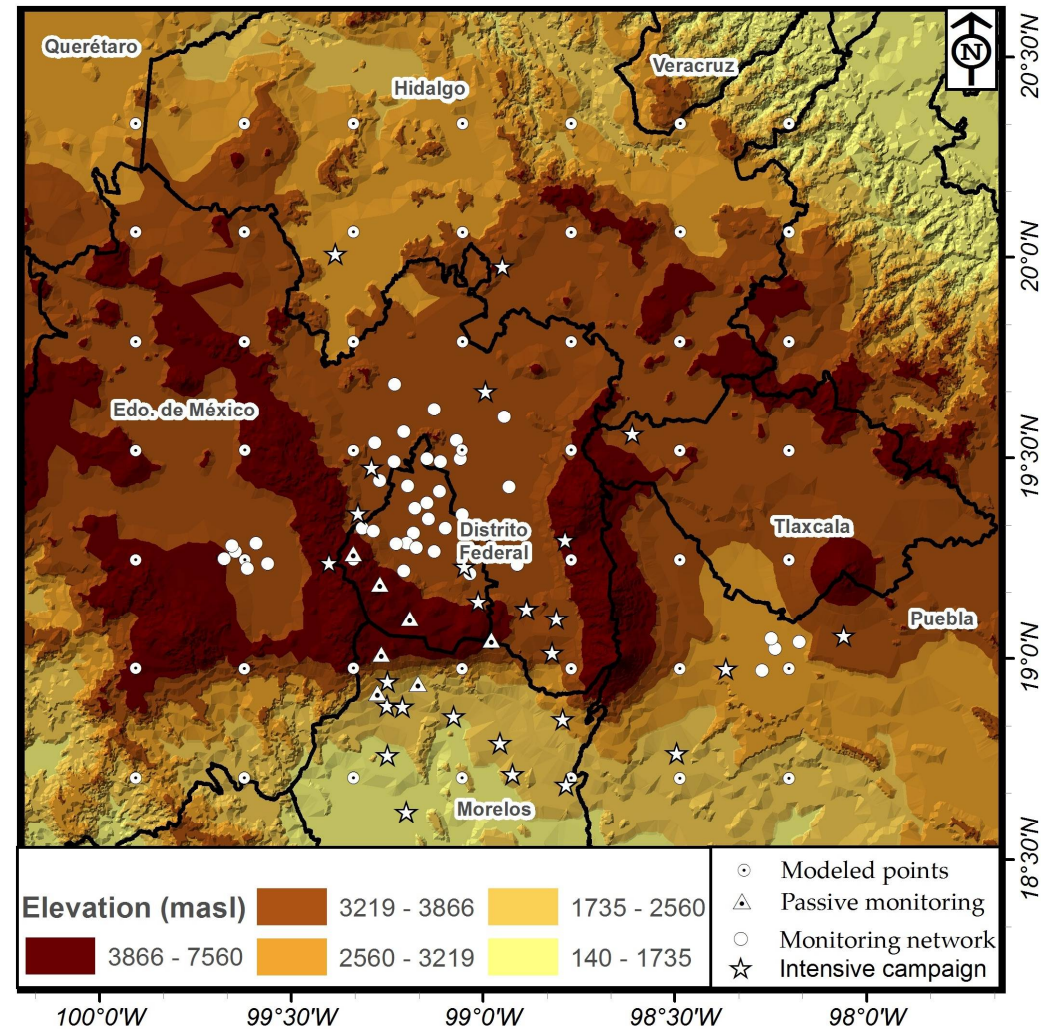

Figure 1. Study area with orography and boundaries between federal states and Mexico City. Four data point categories are shown.

Passive samplers are regarded as a practical choice for measuring ambient ozone concentrations for the purposes of atmospheric chemistry and ecological assessment [22,23]. They are inexpensive and easy to deploy in the field, requiring no power supply or supporting equipment, and they also offer flexibility of placement. These features make them attractive for monitoring in rural areas and in difficult environments, such as within the forest canopy [24]. However, they only provide continuous cumulative values without differentiating day from night. To obtain AOT40 estimates based on measurements with passive samplers, it is necessary to correct the total quantity of $\mathrm{O}_{3}$ provided by the passive sampler to the equivalent ozone levels for daylight hours above $40 \mathrm{ppb}$. The use of mathematical functions from the Weibull probability family applied to nearby continuous ozone measurements has been the tool used in order to approximate the distribution of hourly $\mathrm{O}_{3}$ concentrations [25]. However, the resulting model must be verified against monitoring stations in the study area, which in the case of Central Mexico are available only in urban areas. Nevertheless, some authors have proposed the use of the concept of relative altitude. This is an empirical statistical approach based on using the difference between the altitude at each point at which ozone levels have been measured and the lowest altitude in each circular area around each measured point [26,27], but this approach may not apply in areas that are under the influence of nearby sources of ozone precursors; it is subject to considerable differences between each particular site in the region [26]. Therefore, exceedance maps for the city belt of Central Mexico cannot be obtained using the statistical modeling nor the relative altitude approaches.

Air quality models have also been used to estimate the formation and transport of ozone over the areas covered by the vegetation of interest $[15,28]$, but the results of the model need to be validated against observations. Additionally, if available, data from monitoring networks can be used to adjust the results of air quality models [29-31]. Tarrasón et al. [29] created difference fields in the simulation domain by interpolating the differences observed between the results of a regional air quality model 
and the measurements taken. This technique allows for correction of the results of the model at any point in the simulation domain. In our case, the absence of rural monitoring stations precluded us from creating such difference fields outside of urban areas.

Damage to vegetation by ozone has been reported for Mexico. These reports have been of a qualitative nature [32,33], or with too coarse resolution in global modeled studies [17]. The same lack of information about ozone in rural areas that hindered quantitative estimates in those early studies still prevails. In this work, we report for the first time in Mexico, the estimated cost of agricultural production loss due to the exposure of several crops of economic importance to high concentrations of ozone present in the city belt of Central Mexico, which includes the Mexico City megalopolis. We address the methodological challenges facing an emerging economy such as that of Mexico in the estimation of the economic impacts of crop ozone exposure and we describe the equity issues that such exposure exacerbates.

\section{Methods}

\subsection{Study Area}

The study region, located in the central region of Mexico, is demarcated by the coordinates $20.6200-18.2276^{\circ} \mathrm{N}$ and $100.2030-97.5693^{\circ} \mathrm{W}$ and has an area of $72,900 \mathrm{~km}^{2}$. It encompasses the states of Morelos, Mexico State, Tlaxcala, and Mexico City and includes parts of the states of Guerrero, Hidalgo, Queretaro, and Puebla. The total population of this region is 33.77 million inhabitants, which represents $31.2 \%$ of the total national population [34]. It has an estimated surface area of rain-fed crops of $28,154 \mathrm{~km}^{2}$ [35].

The following percentages show these states' participation in the current total national GDP values (2011) by primary activity (agriculture, animal breeding and farming, forestry, fishing and hunting): Morelos: 1.2\%; Mexico State: 3.5\%; Tlaxcala: 0.5\%; Mexico City: $0.2 \%$; Guerrero: $2.4 \%$; Hidalgo: $1.9 \%$; Queretaro: 1.3\%; Puebla: 4.1\% [36].

\subsection{Ozone Data}

\subsubsection{Passive Monitoring}

The passive sampler (Ogawa \& Co., USA, Inc., Pompano Beach, FL, USA) consists of a cylindrical polymer body $(2 \times 3 \mathrm{~cm})$ and a plastic pin clip holder. There are two cavities on the ends of the cylinder, each of which holds one coated filter between two stainless steel screens. The passive sampler uses two nitrite-coated filters in the interior part. When exposed to ambient $\mathrm{O}_{3}$, nitrite ion is oxidized to nitrate ion. Both exposed filters are extracted and analyzed by ion chromatography to determine cumulative nitrate concentration for the two-week exposure period. This allows for a determination of average cumulative $\mathrm{O}_{3}$ exposure in $\mathrm{ppb}$ [37].

For analytical determination, a Shimadzu HPLC model CDD-10AVP was used. It is equipped with an isocratic pump LC-20AD and an ionic conductivity detector CD-10A-VP. The column was Shodex SI-90 4E $(4.0 \times 250 \mathrm{~mm}$, particle $9 \mu \mathrm{m})$. The mobile phase was $1.8 \mathrm{mM} \mathrm{Na}_{2} \mathrm{CO}_{3}+$ a $1.7 \mathrm{mM}$ $\mathrm{NaHCO}_{3}$ solution, with a flow of $2.0 \mathrm{~mL} / \mathrm{min}$ and a $200 \mathrm{~mL}$ injection volume. Analysis time was $15 \mathrm{~min}$.

Our implementation of this method was tested by co-colocation of passive samplers with a standard continuous $\mathrm{O}_{3}$ monitor. In two independent experiments, the Ogawa passive samplers always overestimated accumulated $\mathrm{O}_{3}$ concentrations by no more than $10 \%$ in samples taken between 1 day and 3 weeks. The remaining nitrite in the passive sampler followed an exponential decay curve as the sampling period increased, staying in its linear-like part for up to two weeks.

The passive sampling was conducted in a smaller area, the mountain zone south of the MCMA (Figure 1, triangles with dots). 


\subsubsection{Continuous Monitoring}

The MCMA continuous ozone monitoring data were obtained from the databases of the environment authority of Mexico City [38]. Data from the Metropolitan Area of Puebla and from the Metropolitan Area of Toluca were obtained from SINAICA [18]. All of them are represented by empty white circles in Figure 1. Short-term (up to five weeks) continuous data were obtained in several rural and periurban sites within the region using mobile units as part of studies funded for other purposes [39-41] (Figure 1, stars).

\subsection{Maps}

Maps were created using ArcGis software v.10.2 by ESRI, Redlands, CA, USA and consisted of five layers in shapefile format, with Lambert conformal conic projection (LCC), Datum International Terrestrial Reference Frame 92 (ITRF92) epoch 1988.0 (DATUM ITRF92). These layers are as follows: state, municipal, land use administrative boundaries [42], the study area limit (own elaboration), and the final layer, in which the spatial distribution of the ozone exposure index studied in this work, AOT40 for the year 2011, is calculated and represented, with our data.

The maps were created on a 1 ha scale. This exceeds the spatial resolution of the information available to us on agricultural production. It also exceeds the spatial resolution in our Mesoscale Climate and Chemistry Model (MCCM) runs $(3 \mathrm{~km} \times 3 \mathrm{~km})$. However, we kept this resolution because we expect that the government agencies that have information at the parcel level will eventually make it available. We are developing the capability of running WRF-Chem, instead of MCCM at $1 \mathrm{~km}^{2}$ for Central Mexico. For AOT40, the selected interpolation method was kriging, which is widely applied for interpolating air quality data $[31,43,44]$.

\subsection{Exposure-Response Functions}

The exposure-response functions (ERFs) from the literature were derived from open-top chamber studies in which the effect on the growth of plants exposed to different concentrations of ozone was measured. The functions compiled by Mills et al. [12] were used; these functions give a linear exposure-response relationship as a function of the AOT40 metric for the crops studied (Table 1). For sorghum, oats and beans, in the absence of specific functions we choose to use the generic sensitive function suggested by Mills. The functions were modified to force RY $=1.0$ at $x=0$ and $\mathrm{RY}=0.95$ at the critical level $[16,17]$.

Table 1. Exposure-response functions for the four crops of economic interest analyzed in this work in the city belt of Central Mexico [12]. AOT40: accumulated exposure over the threshold of $40 \mathrm{ppb}$.

\begin{tabular}{ccc}
\hline Crop & ERFs Used for RYL Calculation, AOT40 [ppm·h] & Critical Level * [ppm·h] \\
\hline Maize & $-0.0035 *$ AOT40 & 13.9 \\
Sensitive crops (oats, sorghum, and beans) & $-0.01212 *$ AOT40 & 3 \\
\hline & * For 5\% yield reduction.
\end{tabular}

Production loss per unit area was calculated using the following equation:

$$
C P L_{i}=\frac{R Y L_{i}}{1-R Y L_{i}} * C P_{i}
$$

where $C P L_{i}$ is the crop production loss [t] per unit area $i[\mathrm{ha}], R Y L_{i}$ is the relative yield loss, and $C P_{i}$ is the actual crop yield [t/ha] [16].

Municipal crop production loss used in this study is the mean of the crop production loss in all the crop cells within each municipality.

Finally, the economic damage was calculated using the following equation:

$$
E L_{i}=C P L_{i} * A R P_{i}
$$


where $E L_{i}$ is the value of the economic loss [\$/ha], and $A R P_{i}$ was the average rural price per municipality $[\$ / t]$ in 2011. In Mexico, this is the highest resolution crop price available. Monetary units are current Mexican pesos in 2011. Final aggregate values are given in USD using the average 2011 exchange rate.

\subsection{Statistical Information}

The first tests were carried out using information from the database of "Oficina Estatal de Información para el Desarrollo Rural Sustentable" (OEIDRUS) [45], which provided the spatial distribution of the plots of the crops of interest, with a resolution of 1 ha. Subsequently, we realized that the information available to us regarding other states was very irregular. In order to standardize procedures, we decided to use statistical information available from "Secretaría de Agricultura, Ganadería, Desarrollo Rural, Pesca y Alimentación" (SAGARPA) [46], which provides the following municipal scale information by crop: hectares planted, hectares harvested, average yield per hectare, production value, and average production value.

In order to include a measure of environmental equity associated with externalities arising from air pollution we used the marginalization index, which is defined as a measurement summary that allows for differentiation between locations in the country according to the overall impact of the deficiencies suffered by the population as a result of their lack of access to education and assets, and the fact that many reside in inadequate housing, all of which is associated with a low income [47].

\subsection{Air Quality Model}

The air quality model (AQM) used was the MCCM [48] in its non-hydrostatic mode. The chemical model is consistent with the meteorological model, using both the same transport schemes and the same horizontal and vertical grid. The chemical mechanism was RADM2 [49]. The meteorological information was obtained from the global forecast (GFS). The modeling domain has $73 \times 73$ cells of $3 \times 3 \mathrm{~km}$ and 22 vertical levels. The parametrizations for the cloud radiation scheme were as follows: non-hydrostatic option, Grell's cumulus parameterization, the Burk-Thompson PBL scheme, warm-rain scheme, Reisner scheme for explicit moisture, and a five-layer soil model.

A comprehensive assessment of model performance may be done using a set of metrics. Among them, the index of agreement $I_{C}[50]$ allows for a quick and intuitive verification of model performance.

$$
I_{c}=1-\frac{\sum_{i=1}^{N}\left(p_{i}-o_{i}\right)^{2}}{\sum_{i=1}^{N}\left(\left|p_{i}-\bar{o}\right|+\left|o_{i}-\bar{o}\right|\right)^{2}}
$$

where $p_{i}$ is the model-predicted concentration at time interval $i . o_{i}$ is the hourly average of the observed concentration at time interval $i . I_{c}$ varies from 0 to 1 . When $I_{c}=1$, there is a perfect match between modeled and observed concentration values.

\section{Results and Discussion}

\subsection{Creation of the Exceedance Maps}

The limiting factor for estimating crop loss due to ozone exposure is the availability of cumulative AT40 exceedance maps. The method developed for arriving at a reliable estimate, on the safe side of having sparse information, was the first result of this work. Figure 2 shows a conceptual model of the procedure followed in order to obtain the exceedance maps with the information available in Mexico. The following is a description of the contents of each of the model's nine boxes.

\section{- Box 1}

The first layer of information necessary to obtain the AOT40 exceedance maps was the results from MCCM for January 2009 to July 2011 for the regular grid shown in Figure 1 (white circles with 
dots). The high spatial and temporal resolution emissions model used in the simulations (INEM-AR 2008, Spanish initials), was obtained from the National Emissions Inventory disaggregated to a high spatial resolution $(3 \mathrm{~km} \times 3 \mathrm{~km})$ using by default temporal emissions profiles or local profiles if available. As is commonly necessary in the MCMA, $\mathrm{NO}_{x}$ and VOC emissions were adjusted in order to optimize the adjustment of the $\mathrm{O}_{3}$ profiles modeled using the observations of the local monitoring network [51,52]. In any case, the first task when using the model in each specific application is to evaluate its performance by comparing the results of the model against observations of the MCMA monitoring network during the episode or scenario under study [53] (Figure 1, white empty circles). The $\mathrm{O}_{3}$ comparison between the model and data from several MCMA monitoring stations has an index of agreement greater than 0.81 [54]. The index value decreased to $0.5<I_{c}<0.66$ when compared with the rural and periurban sites monitored during two intensive campaigns [40,41]. The aim of some tasks in the following boxes is to improve on this metric.

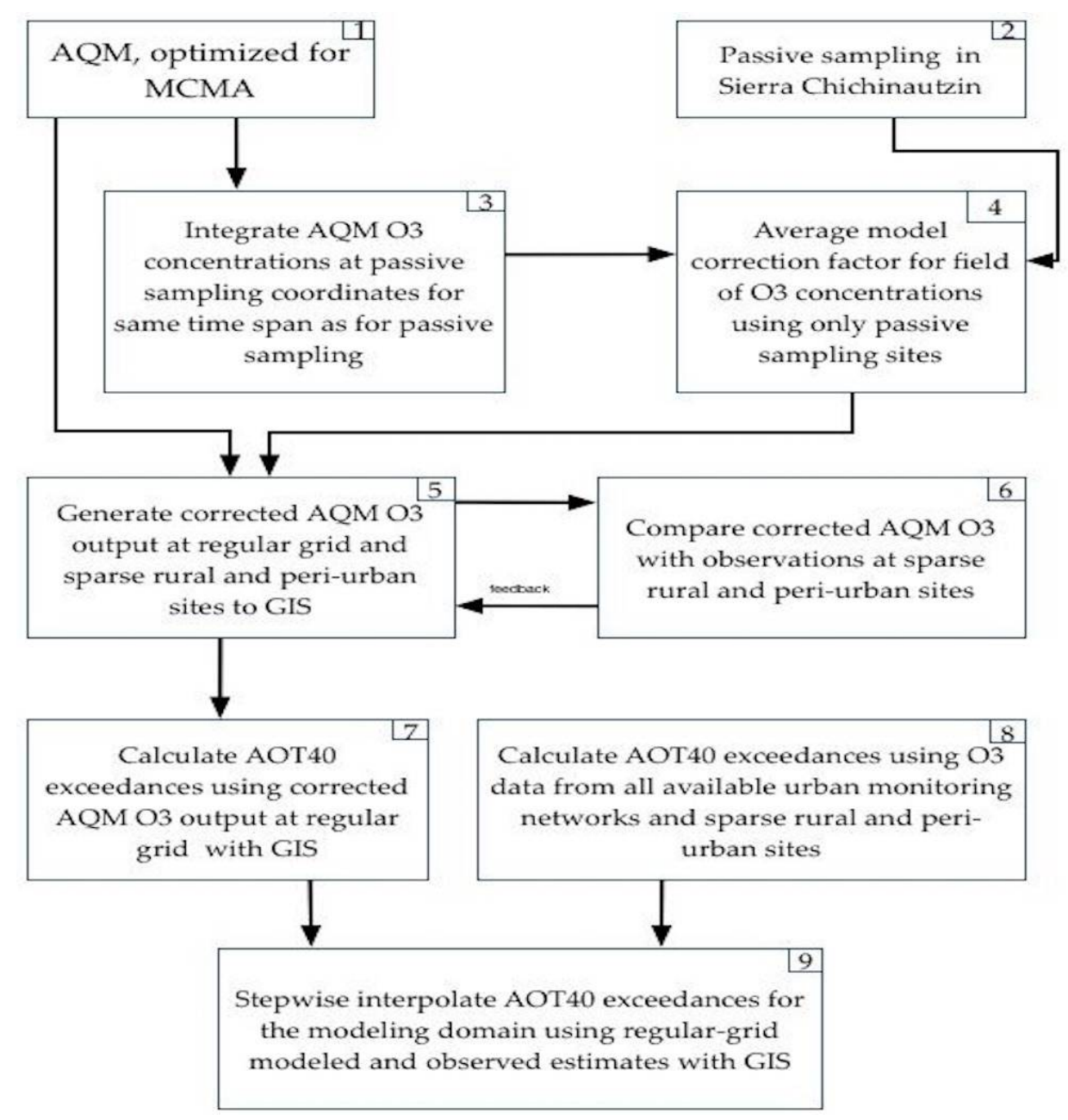

Figure 2. Conceptual model of the process used to obtain the AOT40 exceedance maps.

- $\operatorname{Box} 2$

With a network of seven passive monitors, $\mathrm{O}_{3}$ samples were collected in the Sierra de Chichinautzin (Figure 1, triangles with dots) between 2011 and 2012. In the central region of Mexico, the seasons are divided into cold dry (November-February), warm dry (March-May), and wet (June-October) [55]. Passive samplers were placed in four periods of two weeks each, for two months in each season. Thus, eight samples were collected for each season during the 24 months of the study. 
- Box 3

To prepare the results from the model for comparison with the measurements taken by the passive samplers, which are of lower temporal resolution, the hourly ozone concentrations reported by MCCM were averaged over the two months of sampling for each season, resulting in the MCCM profile shown in Figure 3. The averages over each point of the grid, 12 sites, in the part of the simulation domain that contains the passive monitor sampling region were interpolated in the GIS in order to create a field of modeled averages and thus extract the averages over the passive monitoring sites for comparison.



Figure 3. The average passive monitoring values at any site (Co) and the Mesoscale Climate and Chemistry Model (MCCM) average ( $\mathrm{Cm})$, which is obtained by averaging the profile with the hourly means from MCCM calculated over the two-month passive sampling period.

- $\operatorname{Box} 4$

The average value of the modeled field extracted at the passive sampling sites $\left(\mathrm{Cm}_{\mathrm{i}}\right)$ was compared with the average of the results observed with the passive samplers during the two months at the site $\left(C_{o_{i}}\right)$ as follows:

$$
C_{m}=\frac{\sum_{i=1}^{n} C_{p_{i}}}{n}
$$

where $C_{m}$ is the mean of the modeled concentrations from MCCM for the period of time similar to the passive monitoring time. $C_{p}$ is the concentration predicted by the simulation model throughout the simulation period. $n$ is the number of time intervals for the entire simulation period. Simultaneously,

$$
C_{o}=\frac{\sum_{j=1}^{l} C_{j}}{l}
$$

where $C_{o}$ is the mean of the observed concentrations obtained from the passive monitoring operations for the sampling period. $C_{j}$ is the concentration obtained by a passive monitoring operation for a period of 15 days. $l$ is the number of samples collected during a campaign, be it during the cold dry, warm dry, or wet seasons.

For each passive monitoring site,

$$
x=\frac{C_{0}}{C_{m}} .
$$

At this point, a field of adjustment quotients such as that used by Tarrasón et al. [29] can be created, but a review of the exceedance map shows that the region where an interpolation can be applied is very small. Therefore, at this stage, we opted for an average adjustment factor for the 
MCCM results. An average adjustment factor for the results of the model in the entire region was obtained as follows:

$$
\overline{\mathcal{X}}=\frac{1}{n} \sum_{i=1}^{n} x_{i}
$$

Table 2 shows the correction factors obtained for the passive sampling sites. The wet season data could not be used because, in that season, at all those sites, saturated relative humidity conditions are persistent; this causes condensation in the passive sampler. There is no specific pattern. Tres Marías is a small community in the State of Morelos that is under the influence of the Mexico City-Cuernavaca toll and non-toll highways. However, Parres, in Mexico City, is also under the influence of the same highways. Only Desierto de los Leones site showed the opposite ratio.

Table 2. Empirical correction factors for $x=c_{o} / c_{m}$ showing that MCCM systematically underestimates $\mathrm{O}_{3}$ in the rural sites sampled using passive monitors, with $\bar{X}=2.06 \pm 1.0$.

\begin{tabular}{cccccccc}
\hline & Tres Marías & CICS & $\begin{array}{c}\text { Desierto de } \\
\text { los Leones }\end{array}$ & $\begin{array}{c}\text { Lomas de } \\
\text { Ahuatlan }\end{array}$ & Parres & Santa Catarina & San Nicolas \\
\hline Cold dry 2009 & 3.21 & 1.63 & 1.14 & 1.48 & 2.29 & 3.02 & 1.68 \\
Cold dry 2010 & 4.20 & 1.64 & 1.13 & 1.50 & 2.05 & 4.37 & 1.52 \\
Cold dry 2011 & 3.40 & 1.58 & 1.09 & 1.45 & 2.21 & 3.16 & 1.62 \\
Cold dry average & 3.60 & 1.62 & 1.12 & 1.48 & 2.18 & 3.52 & 3.26 \\
Warm dry 2009 & 3.24 & 1.37 & 0.76 & 1.53 & 2.02 & 3.68 & 1.29 \\
Warm dry 2010 & 3.50 & 1.37 & 0.79 & 1.54 & 1.95 & 3.58 & 1.30 \\
Warm dry 2011 & 3.39 & 1.37 & 0.76 & 1.51 & 1.92 & 3.51 \\
Warm dry average & 3.37 & 1.37 & 0.77 & 1.52 & 1.96 & 3.51 \\
Dry season average & 3.49 & 1.49 & 0.94 & 1.50 & 2.07 & 1.28 \\
Std dev cold + warm dry & 0.36 & 0.14 & 0.19 & 0.03 & 0.15 & 0.49 & 1.44 \\
\hline
\end{tabular}

- Boxes 5 and 6

In 2011 and 2012, our group carried out three intensive monitoring campaigns at several sites in two regions of the city belt of Central Mexico. The sites selected were rural or periurban. From the 2011 campaign [40], the Amecameca site was chosen. This site, located in the State of Mexico at the Tenango del Aire mountain pass, connects the Valley of Mexico with the valleys of Cuautla and Cuernavaca. From the 2012 campaign [41], the Chipilo site was chosen, and they were used as described below.

With the adjustment factor obtained in Box 4, the results of the model were corrected at all grid points and at the coordinates of the mobile units in Amecameca and Chipilo for the periods of time during which the campaigns were carried out; these corrected results were compared with the hourly profiles observed at those sites. At the urban sites, the comparison showed that the model results corrected with the average adjustment value obtained from passive monitoring considerably overestimated the reported values; however, for Amecameca and Chipilo, the comparison showed that the daytime profiles of the corrected model are more similar to the observations, with an overestimate between 10 and 30\%. For completeness, a small additional correction was made. The nighttime profiles are also overestimated, a possible sign of the absence of enough nocturnal NO emissions in the emissions inventory. During nighttime, excess modeled boundary layer height and/or wind intensity could also reduce the NO concentrations available to titrate $\mathrm{O}_{3}$. These results are also valuable in top-down validations of emissions inventories, but that is the object of another work to be reported elsewhere. With two sites, a nighttime adjustment factor of 0.47 was obtained, from 19:00 to 07:00 h. Its impact on the AOT40 indicator is small, producing an effect only at dawn and at dusk. Nevertheless, it was applied so as not to overestimate the calculation of the AOT40 indicator for those two hours. At this stage, comparison of modeled and observed concentrations in the rural and periurban available pairs of data yielded much better values of the index of agreement $0.62<I_{\mathcal{C}}<0.90$.

- $\quad$ Box 7

With the results from MCCM optimized for the MCMA, the hourly ozone profiles were obtained for the 2011 crop season. These profiles, for all sites in the regular grid, were corrected with the daytime 
and nighttime adjustment factors, and the AOT40 indicator was obtained for all points of the regular grid, using the kriging interpolating method (Map a, Figure 4).

- $\quad$ Box 8

The values of the AOT40 indicator were obtained for all monitoring sites with data from the local MCMA network (RAMA) and that of the Metropolitan Area of Puebla (REMA) and added to the interpolating data set yielding Map $\mathrm{b}$ in Figure 4. These allowed for the correction, in urban areas, of the overestimation in the interpolation introduced by the indiscriminate use of the adjustment factor applied to the results of the model. In the absence of sufficient data from a station, the exceedances for the growing period were estimated using a ratio proportional to the number of observation days [26].

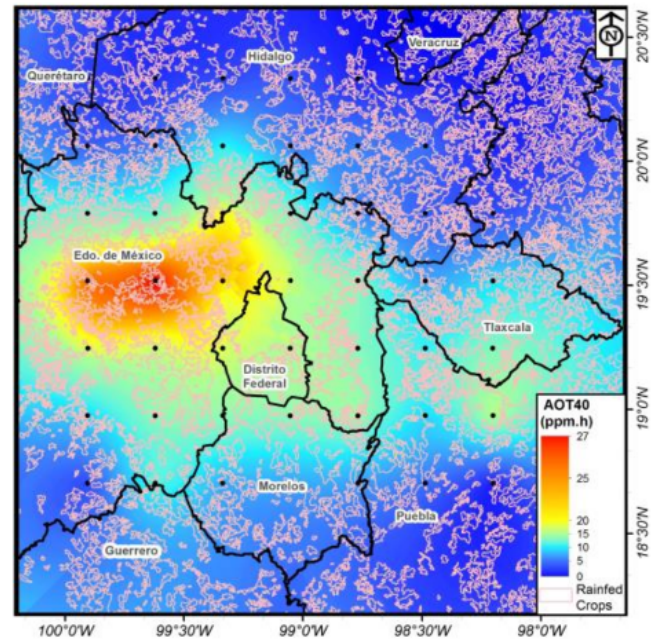

(a)

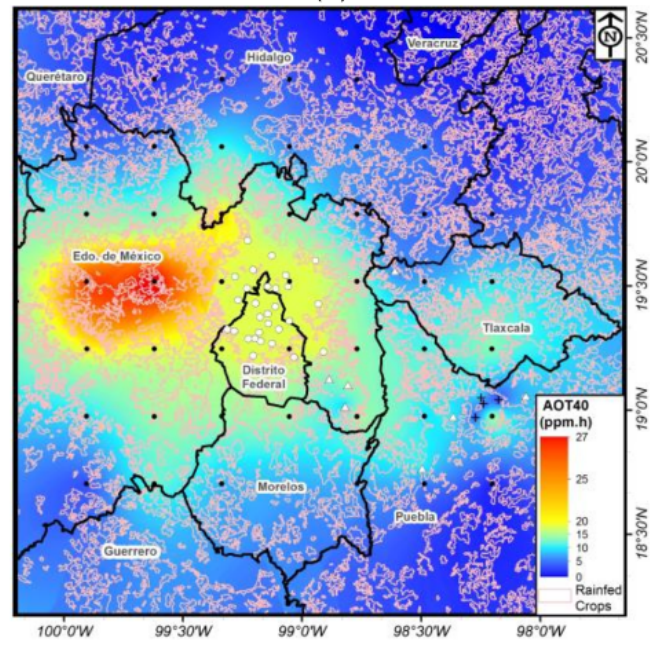

(c)

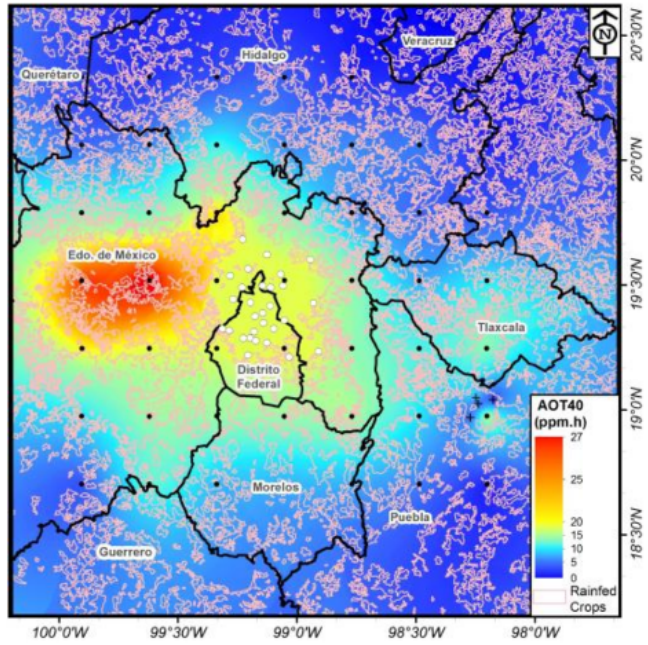

(b)

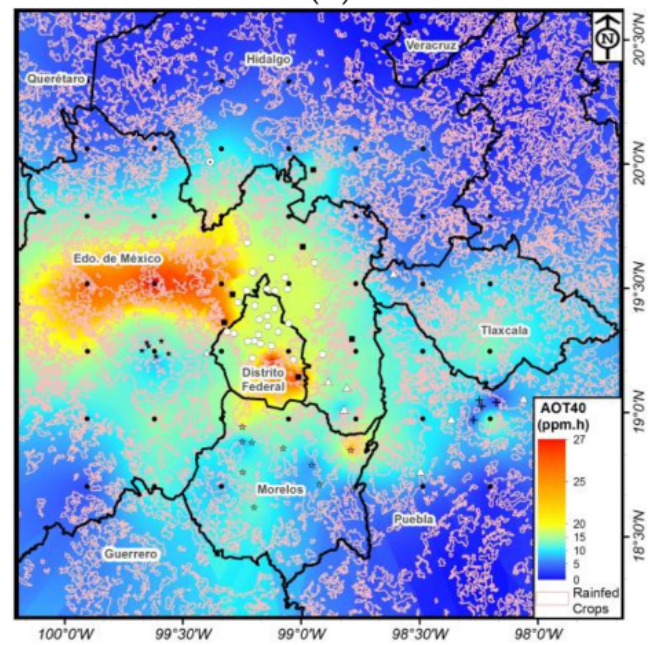

(d)

Figure 4. Evolution of the hybrid exceedance maps as observational data were gradually added to correct the maps obtained only with the air quality model. (a) Using only modeled and corrected regular grid points. (b) Panel (a) + RAMA + REMA. (c) Panel (b) + García-Yee + Barrera-Huertas. (d) Panel (c) + MILAGRO + CARIEM + Tula.

- $\quad$ Box 9

The AOT40 indicator calculated for the rural and periurban sites in the 2011 [40] and 2012 [56] campaigns were then appended to the interpolating data set, yielding Figure 4c. 
At this point, we still have some data from a few rural sites not yet used and must decide if it is safe to use them. Some were from the campaign carried out in 2009 in the State of Morelos (CARIEM) [39]. We also had data from some sites, obtained by the mobile unit of the air quality monitoring system of the State of Mexico between 2006 and 2009, two sites, Tula [57] and ININ [58] plus data for periurban sites during MILAGRO [59]. The AOT40 indicator was estimated for all of these sites. We decided it was safe to use them after the following empirical analysis.

In total, we had 16 data sets from short time campaigns. Two (AME and CHI) were used to confirm the use of the single average adjustment factor. Two from the 2011 campaign, OZU and TEN, and three from the 2012 campaign, AMO, CA, and HUA, had already been used to obtain the map in Figure 4c. To produce the final map (Figure 4d), we added the estimated AOT40 exceedance of the remaining nine rural and periurban sites to the interpolating data and analyzed the resulting map. Altogether, when making Figure 4c,f, of the 16 sites, 11 of them warmed the colors to the already adjusted map. Five of them modulated an excess correction by the average adjustment factor

In the absence of a region wide of several years of AOT40 exceedance data, Figure $4 \mathrm{~d}$ offers the best representation possible of the AOT40 exceedance using the available information for July-September months. We call it a hybrid map, as it uses results of a mesocale air quality model fed with the 2008 INEM-AR emissions inventory and driven by 2011 meteorology. These estimates were corrected with passive sampling data collected during 2011 and 2012 and with short-term continuous monitoring data in rural and periurban sites, 16 sites, in four field campaigns in 2006, 2009, 2011, and 2012.

Figure $4 \mathrm{~d}$ is consistent with some known facts that help to explain the shapes and shades on the maps. The parts of the map with the greatest accumulation of exceedances, the hottest parts, are the high-altitude $\mathrm{O}_{3}$ in the higher parts of the Sierra Nevada to the east of the MCMA, the Sierra Chichinautzin to the south, and the Sierra de las Cruces to the west of the MCMA; on the other hand, the red patch to the north of the Toluca Valley Metropolitan Area (TVMA) represents a net receptor area of air masses, rich in ozone and still photochemically active, arriving, depending on the dominant direction of surface winds, from the TVMA [60] to the south-southwest, from the MCMA $[61,62]$ to the east, or from the Tula-Tepeji industrial zone [63] to the north. The impact of the Tula-Tepeji industrial zone on the MCMA is well documented [54,63]; however, due to the presence of the Sierra de las Cruces, a difference of only a few degrees can divert emissions from Tula-Tepeji towards the TVMA instead of MCMA.

The maps in Figure 4 show that the parts with the lower AOT40 exceedances systematically correspond to areas where there is no measurement of ozone, despite the upward correction with a constant factor of the MCCM results. Additionally, in Figure 4a-d, in most cases, as the scarce observational data from rural and periurban sites not previously used were added to the interpolation database, the map showed warmer colors meaning higher AOT40 exceedances. This supports the following hypothesis: It is highly likely that the cumulative estimate of injury to vegetation and economic costs due to ozone exposure in the city belt of Central Mexico will be an underestimate of the actual costs and damages.

\subsection{Estimation of Economic Losses}

Figure $5 \mathrm{a}-\mathrm{f}$ shows the results of the application of Equations (1)-(3) to the corresponding layers of information in the GIS. Table 3 shows input values and results from the application of Equations (1)-(3) in the 20 municipalities most affected by the exposure of maize to ozone throughout the simulation domain.

The impacts are not homogeneous in the region; they depend on the production of the crop, on the planted area, the cumulative AOT40, and the price paid to the farmer, which is not the same in all municipalities. For example, in the case of maize, Table 3 shows that the farmers in the municipality of Huamantla in the State of Tlaxcala lost 3\% of their production due to ozone exposure. The estimated value of their production is 156 million pesos MXN and the economic loss is 5 million pesos MXN. In the municipality of Villa de Allende in the State of Mexico farmers lost 7\% of their 
production due to ozone exposure. The estimated value of their production is 152 million pesos MXN, and the economic loss is 11 million pesos MXN. In terms of equity, it can be observed that the degree of urban marginalization, used here as a euphemism for poverty, in Huamantla is low, and in Villa de Allende it is high; surely such a potential loss of income represents a high cost to already impoverished communities.

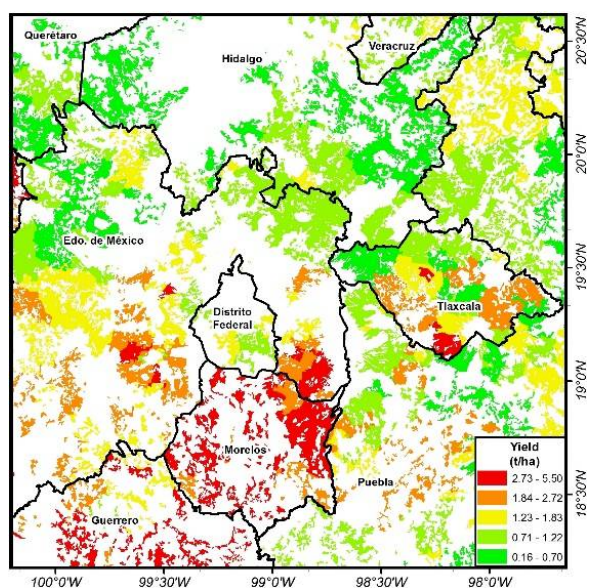

(a)



(c)

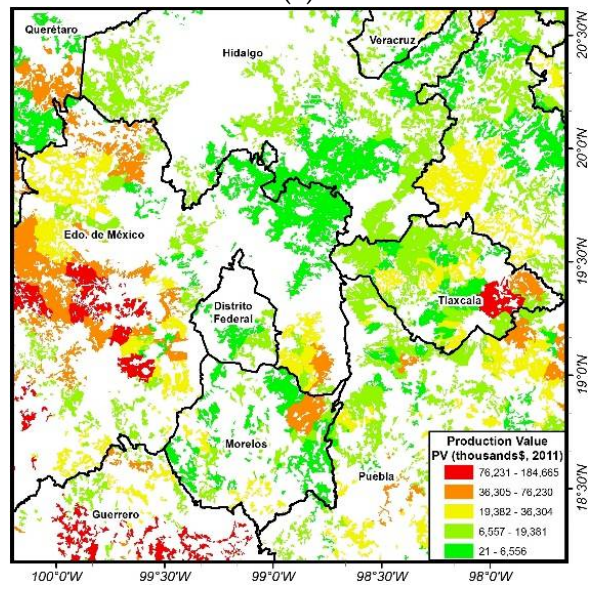

(e)

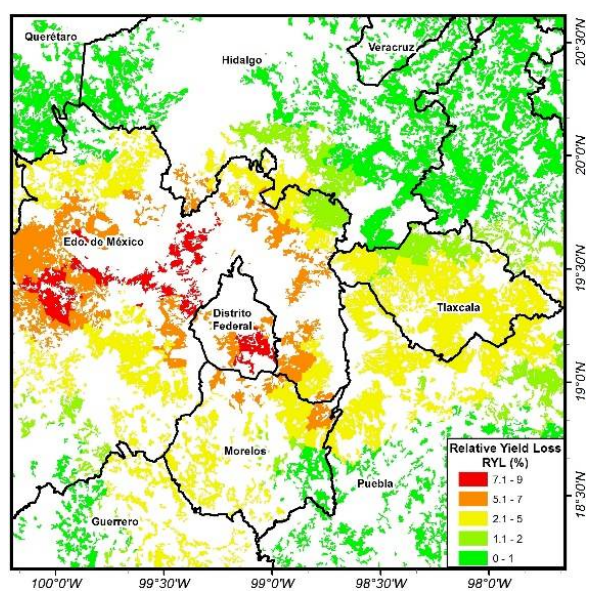

(b)

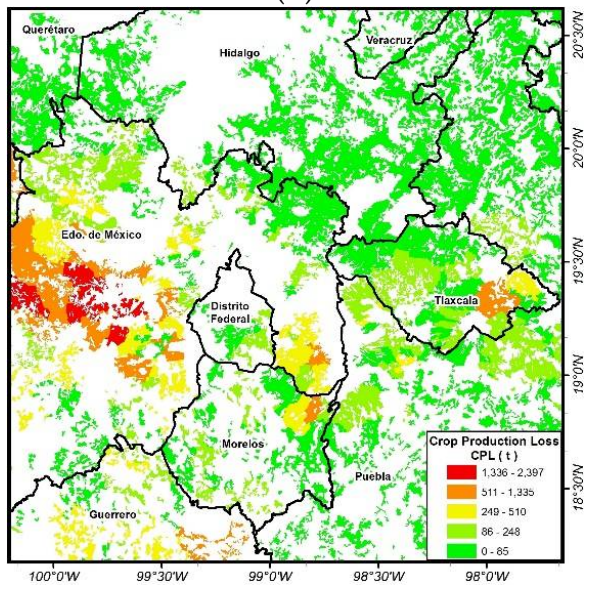

(d)

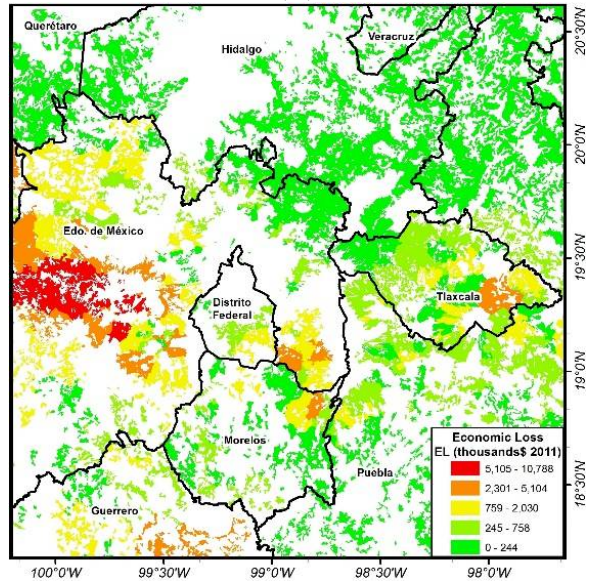

(f)

Figure 5. Maize: (a) Yield (t/ha). (b) Relative yield loss (\%). (c) Production (t). (d) Crop production loss (t). (e) Production value (MXN). (f) Economic loss (MXN), for 2011. 
Table 3. Results for 2011 in the 20 municipalities most affected in terms of maize production, showing the input values and the results of the application of Equations (1)-(3) in the geographic information system (GIS).

\begin{tabular}{|c|c|c|c|c|c|c|c|c|c|c|}
\hline State & Municipality & $\begin{array}{l}\text { AOT40 } \\
(\mathrm{ppm} \cdot \mathrm{h})\end{array}$ & $\begin{array}{l}\text { Relative Yield } \\
\text { Loss (\%) }\end{array}$ & $\begin{array}{l}\text { Yield } \\
\text { (t/ha) }\end{array}$ & $\begin{array}{l}\text { Yield Loss } \\
\text { (t/ha) }\end{array}$ & $\begin{array}{l}\text { Economic Loss/ha } \\
\text { (MXN/ha) }\end{array}$ & $\begin{array}{c}\text { Sown Area } \\
\text { (ha) }\end{array}$ & $\begin{array}{c}\text { Production Value } \\
\text { (Millions of Pesos MXN) }\end{array}$ & $\begin{array}{c}\text { Economic Loss } \\
\text { (Millions of Pesos MXN) }\end{array}$ & $\begin{array}{c}\text { Degree of } \\
\text { Marginalization }\end{array}$ \\
\hline Mexico & Villa de Allende & 23.98 & 7 & 2.50 & 0.18 & 799 & 13,500 & 152 & 11 & High \\
\hline Mexico & Toluca & 18.28 & 5 & 2.50 & 0.12 & 497 & 17,822 & 185 & 9 & Very low \\
\hline Mexico & Almoloya de Juarez & 24.95 & 7 & 1.34 & 0.10 & 382 & 21,000 & 107 & 8 & Medium \\
\hline Mexico & Villa Victoria & 25.84 & 7 & 1.40 & 0.11 & 496 & 12,100 & 76 & 6 & High \\
\hline Tlaxcala & Huamantla & 14.33 & 3 & 2.40 & 0.08 & 352 & 14,480 & 156 & 5 & Low \\
\hline Mexico & Tenango del Valle & 18.05 & 4 & 2.60 & 0.12 & 520 & 8891 & 98 & 5 & Low \\
\hline Mexico & Ixtlahuaca & 27.40 & 8 & 0.80 & 0.07 & 313 & 12,903 & 47 & 4 & Medium \\
\hline Mexico & Lerma & 21.83 & 6 & 1.50 & 0.09 & 355 & 9989 & 57 & 4 & Very low \\
\hline Mexico & San Jose del Rincón & 23.25 & 6 & 0.85 & 0.06 & 246 & 13,173 & 48 & 3 & High \\
\hline Mexico & Amecameca & 18.31 & 5 & 3.27 & 0.16 & 699 & 4553 & 66 & 3 & Low \\
\hline Mexico & Temoaya & 26.28 & 7 & 1.94 & 0.16 & 556 & 5600 & 39 & 3 & Medium \\
\hline Mexico & Zinacantepec & 18.95 & 5 & 1.66 & 0.08 & 320 & 9557 & 60 & 3 & Low \\
\hline Mexico & Tianguistenco & 19.76 & 5 & 2.50 & 0.13 & 579 & 5251 & 56 & 3 & Low \\
\hline Mexico & Amanalco & 22.16 & 6 & 1.60 & 0.10 & 458 & 6500 & 47 & 3 & Medium \\
\hline Guerrero & Huitzuco & 13.84 & 3 & 3.00 & 0.09 & 322 & 8971 & 94 & 3 & High \\
\hline Mexico & Donato Guerra & 22.81 & 6 & 1.32 & 0.09 & 394 & 7200 & 43 & 3 & High \\
\hline Michoacan & Zitacuaro & 23.74 & 7 & 1.75 & 0.12 & 359 & 7550 & 39 & 3 & Medium \\
\hline Morelos & Ocuituco & 23.60 & 6 & 3.18 & 0.22 & 838 & 3010 & 36 & 3 & Medium \\
\hline Guerrero & Iguala & 11.32 & 2 & 5.50 & 0.12 & 560 & 4337 & 114 & 2 & Low \\
\hline \multirow[t]{2}{*}{ Michoacan } & Contepec & 14.55 & 3 & 3.00 & 0.10 & 271 & 8545 & 69 & 2 & Medium \\
\hline & Total & & & & & & 194,932 & 1590 & 85 & \\
\hline
\end{tabular}


The total production value for maize in these 20 municipalities was 1.590 billion pesos MXN, and, due to ozone exposure, 85 million pesos MXN (5\%) were lost. In the entire simulation domain, the value of maize production in 2011 was 6.598 billion pesos MXN; 46,641 tons were lost to yield reduction, and the value of that unfulfilled production was 191 million pesos MXN. This represents 3\% of the potential production.

The same procedure was performed to estimate the effect of ozone exposure in oats, beans, and sorghum, which are more sensitive to ozone than maize. Table 4 shows the economic loss for each of the four crops throughout the simulation domain. The total economic loss was 671 million pesos MXN, which at the 2011 exchange rate equals 50 million USD. For the other crops, the relative impact of the degree of marginalization was not uniform in the municipalities that make up the simulation domain. It is also clear that these costs may be underestimated due to the likely underestimation of the AOT40 exceedances in the areas of the map with colder colors.

Table 4. Planted area, production value, and economic loss estimated for four crops of economic importance in the city belt of Central Mexico.

\begin{tabular}{cccc}
\hline Crop & Sown Area (ha) & $\begin{array}{c}\text { Production Value } \\
\text { (In Millions of Pesos MXN) }\end{array}$ & $\begin{array}{c}\text { Economic Loss } \\
\text { (In Millions of Pesos MXN) }\end{array}$ \\
\hline Maize & $1,132,150$ & 6598 & 191 \\
Oats (grain) & 26,087 & 98 & 25 \\
Oats (forage) & 153,154 & 1133 & 310 \\
Beans & 61,128 & 357 & 51 \\
Sorghum & 53,524 & 620 & 94 \\
\hline
\end{tabular}

\section{Conclusions}

This work is the first attempt to estimate the cost of air pollution in Mexico, in terms of its impact on agriculture. Maize, the most important cereal in the Mexican diet, showed low sensitivity to ozone and economic losses of up to 3\%. However, if the other crops are as sensitive as their proxies, then farmers who grow beans may lose up to $14 \%$ in potential revenue. Those farming sorghum may lose $15 \%$, and for oats the loss may be up to $26 \%$ of the yield under optimal growth conditions. The impact on other species such as vegetables, which are highly sensitive to ozone and are cultivated near the cities, was not estimated, nor was the impact on species that are native to Mexico and economically important in the region, such as nopal and agave, due to the lack of exposure-response functions, even by proxy.

This attempt comes more than 30 years after continuous ozone monitoring was first performed in Mexico. It has been done with almost non-existent information for the affected rural areas. Although it is incomplete, the evidence accumulated by the incorporation of data from rural and periurban sites seems to show that, in terms of AOT40 exceedance maps, the costs reported here may be an underestimation.

The other source of uncertainty or bias is the use of proxy species which points to the need for national or local determination of exposure-response functions for crops of economic importance not reported previously in the literature.

It is evident that the agricultural areas affected by the metropolitan areas of the city belt of Central Mexico are strongly influenced by the cumulative AOT40 exceedances. Some of the affected municipalities are ranked high on the marginality index, tightening the screw on already-impoverished farming communities.

It falls upon the decision-makers and the affected groups to decide if the information provided here is sufficient to initiate actions for the mitigation of the impacts that negatively affect the availability of food and reduce the sustainability of the agricultural activities in the region. The first of such actions should be the long-term rural monitoring of air pollutants nationwide. 
Author Contributions: Luis Gerardo Ruiz-Suárez wrote the paper and conceived and designed the project and the field campaigns; Bertha Eugenia Mar-Morales was in charge of the GIS calculations and maps; José Agustin García-Reynoso was responsible for the AQM work; Gema Luz Andraca-Ayala was in charge of the passive sampling, lab and data analysis; Ricardo Torres-Jardón was in charge of the mobile unit observations in all the periurban and rural sites; José Santos García-Yee carried out the day-to-day work and data analysis of the 2011 field campaign; Hugo Alberto Barrera-Huertas carried out the day-to-day work and data analysis of the 2012 field campaign; Arturo Gavilán-García and Roberto Basaldud-Cruz were liaisons with INECC and assisted with information collection.

Acknowledgments: This study was conducted with support from the following projects: Conacyt/Semarnat 2006 23081, Conacyt/Fomix PUE-2007-C01-77293, and UNAM/INECC INECC/A1-004/2014 (Ecaim). The air quality model was run using high performance computing provided be DGTIC-UNAM. We also wish to recognize Patrick Weill for his translation of this work into English, with support from Conacyt 280403 (RedCAM).

Conflicts of Interest: The authors declare no conflict of interest.

\section{References}

1. Thompson, A.M.; Yorks, J.E.; Miller, S.K.; Witte, J.C.; Dougherty, K.M.; Morris, G.A.; Baumgardner, D.; Ladino, L.; Rappenglück, B. Tropospheric ozone sources and wave activity over Mexico City and Houston during MILAGRO/Intercontinental Transport Experiment (INTEX-B) Ozonesonde Network Study, 2006 (IONS-06). Atmos. Chem. Phys. 2008, 8, 5113-5125. [CrossRef]

2. Felzer, B.S.; Cronin, T.; Reilly, J.M.; Melillo, J.M.; Wang, X. Impacts of ozone on trees and crops. C. R. Geosci. 2007, 339, 784-798. [CrossRef]

3. Logan, J.A. Tropospheric ozone: Seasonal behavior, trends, and anthropogenic influence. J. Geophys. Res. Atmos. 1985, 90, 10463-10482. [CrossRef]

4. Gregg, J.W.; Jones, C.G.; Dawson, T.E. Urbanization effects on tree growth in the vicinity of New York City. Nature 2003, 424, 183-187. [CrossRef] [PubMed]

5. Mauzerall, D.L.; Wang, X. Protecting agricultural crops from the effects of tropospheric ozone exposure: Reconciling science and standard setting in the United States, Europe, and Asia. Annu. Rev. Energy Environ. 2001, 26, 237-268. [CrossRef]

6. Ganguly, N.D.; Tzanis, C. Study of stratosphere-troposphere exchange events of ozone in India and Greece using ozonesonde ascents. Meteorol. Appl. 2011, 18, 467-474. [CrossRef]

7. De Bauer, M.D.; Hernandez-Tejeda, T. A review of ozone-induced effects on the forests of central Mexico. Environ. Pollut. 2007, 147, 446-453. [CrossRef] [PubMed]

8. Hayes, F.; Mills, G.; Harmens, H.; Norris, D. Evidence of Widespread Ozone Damage to Vegetation in Europe (1990-2006); ICP Vegetation Programme Coordination Centre, CEH: Bangor, UK, 2007.

9. Avnery, S.; Mauzerall, D.L.; Liu, J.; Horowitz, L.W. Global crop yield reductions due to surface ozone exposure: 1. Year 2000 crop production losses and economic damage. Atmos. Environ. 2011, 45, 2284-2296. [CrossRef]

10. Fuhrer, J.; Skärby, L.; Ashmore, M.R. Critical levels for ozone effects on vegetation in Europe. Environ. Pollut. 1997, 97, 91-106. [CrossRef]

11. Fuhrer, J. Critical level for ozone to protect agricultural crops: Interaction with water availability. Water Air Soil Pollut. 1995, 85, 1355-1360. [CrossRef]

12. Mills, G.; Buse, A.; Gimeno, B.; Bermejo, V.; Holland, M.; Emberson, L.; Pleijel, H. A synthesis of AOT40-based response functions and critical levels of ozone for agricultural and horticultural crops. Atmos. Environ. 2007, 41, 2630-2643. [CrossRef]

13. Musselman, R.C.; Lefohn, A.S.; Massman, W.J.; Heath, R.L. A critical review and analysis of the use of exposure- and flux-based ozone indices for predicting vegetation effects. Atmos. Environ. 2006, 40, 1869-1888. [CrossRef]

14. Krupa, S.V.; Manning, W.J. Atmospheric ozone: Formation and effects on vegetation. Environ. Pollut. 1988, 50, 101-137. [CrossRef]

15. Vlachokostas, C.; Nastis, S.A.; Achillas, C.; Kalogeropoulos, K.; Karmiris, I.; Moussiopoulos, N.; Chourdakis, E.; Banias, G.; Limperi, N. Economic damages of ozone air pollution to crops using combined air quality and GIS modelling. Atmos. Environ. 2010, 44, 3352-3361. [CrossRef] 
16. Van Dingenen, R.; Dentener, F.J.; Raes, F.; Krol, M.C.; Emberson, L.; Cofala, J. The global impact of ozone on agricultural crop yields under current and future air quality legislation. Atmos. Environ. 2009, 43, 604-618. [CrossRef]

17. Chuwah, C.; van Noije, T.; van Vuuren, D.P.; Stehfest, E.; Hazeleger, W. Global impacts of surface ozone changes on crop yields and land use. Atmos. Environ. 2015, 106, 11-23. [CrossRef]

18. Instituto Nacional de Ecología y Cambio Climático (INECC). Sistema Nacional de Indicadores de Calidad del Aire. Available online: http:/ / sinaica.inecc.gob.mx/ (accessed on 9 March 2018).

19. Semarnat. Programa de Gestión Federal para Mejorar la Calidad del Aire de la Megalópolis 2017-2030; Semarnat: Ciudad de México, México, 2017; p. 330.

20. Goldan, P.D.; Trainer, M.; Kuster, W.C.; Parrish, D.D.; Carpenter, J.; Roberts, J.M.; Yee, J.E.; Fehsenfeld, F.C. Measurements of hydrocarbons, oxygenated hydrocarbons, carbon monoxide, and nitrogen oxides in an urban basin in Colorado: Implications for emission inventories. J. Geophys. Res.-Atmos. 1995, 100, 22771-22783. [CrossRef]

21. Coyle, M.; Smith, R.I.; Stedman, J.R.; Weston, K.J.; Fowler, D. Quantifying the spatial distribution of surface ozone concentration in the UK. Atmos. Environ. 2002, 36, 1013-1024. [CrossRef]

22. Krupa, S.V.; Legge, A.H. Passive sampling of ambient, gaseous air pollutants: An assessment from an ecological perspective. Environ. Pollut. 2000, 107, 31-45. [CrossRef]

23. Carmichael, G.R.; Ferm, M.; Thongboonchoo, N.; Woo, J.-H.; Chan, L.Y.; Murano, K.; Viet, P.H.; Mossberg, C.; Bala, R.; Boonjawat, J. Measurements of sulfur dioxide, ozone and ammonia concentrations in Asia, Africa, and south America using passive samplers. Atmos. Environ. 2003, 37, 1293-1308. [CrossRef]

24. Cox, R.M.; Malcolm, J.W. Passive ozone monitoring for forest health assessment. Water Air Soil Pollut. 1999, 116, 339-344. [CrossRef]

25. Krupa, S.; Nosal, M.; Peterson, D.L. Use of passive ambient ozone $\left(\mathrm{O}_{3}\right)$ samplers in vegetation effects assessment. Environ. Pollut. 2001, 112, 303-309. [CrossRef]

26. Gerosa, G.; Ferretti, M.; Bussotti, F.; Rocchini, D. Estimates of ozone aot40 from passive sampling in forest sites in south-western Europe. Environ. Pollut. 2007, 145, 629-635. [CrossRef] [PubMed]

27. Loibi, W.; Winiwarter, W.; Kopsca, A.; Zufger, J.; Baumann, R. Estimating the spatial distribution of ozone concentrations in complex terrain. Atmos. Environ. 1994, 28, 2557-2566. [CrossRef]

28. Simpson, D. Photochemical model calculations over Europe for two extended summer periods: 1985 and 1989. Model results and comparison with observations. Atmos. Environ. Part A Gen. Top. 1993, 27, 921-943. [CrossRef]

29. Tarrasón, L.; Semb, A.; Hjellbrekke, A.G.; Tsyro, S.; Schaug, J.; Bartnicki, J.; Solberg, S. Geographical Distribution of Sulphur and Nitrogen Compounds in Europe Derived both from Modelled and Observed Concentrations; 71; Norwegian Meteorological Institute: Kjeller, Norway, 1998.

30. Bush, T.; Targa, J.; Stedman, J. UK Air Quality Modelling for Annual Reporting 2004 on Ambient Air Quality Assessment under Council Directives 96/62/EC and 2002/3/EC Relating to Ozone in Ambient Air; Department for Environment, Food and Rural Affairs, Welsh Assembly Government, the Scottish Executive and the Department of the Environment for Northern Ireland: Didcot, UK, 2007.

31. Denby, B.; Horálek, O.J.; Walker, S.E.; Eben, K.; Fiala, J. Interpolation and Assimilation Methods for European Scale Air Quality Assessment and Mapping Part I: Review and Recommendations; European Topic Centre on Air and Climate Change: Bilthoven, The Netherlands, 2005; p. 51.

32. De Bauer, L.I.; Krupa, S.V. The valley of Mexico: Summary of observational studies on its air quality and effects on vegetation. Environ. Pollut. 1990, 65, 109-118. [CrossRef]

33. Ortíz-García, C.F.; Laguette-Rey, H.D.; de Bauer, L.I. Effects of oxidants in ambient air on annual crops in the basin of Mexico. In Urban Air Pollution and Forests. Ecological Studies (Analysis and Synthesis); Fenn, M.E., de Bauer, L.I., Hernández-Tejeda, T., Eds.; Springer: New York, NY, USA, 2002; Volume 156, pp. 320-333.

34. Instituto Nacional de Estadística y Geografía (INEGI). Censo de Población y Vivienda 2010. Principales Resultados por Área Geoestadística Básica (AGEB); Instituto Nacional de Estadística y Geografía: Aguascalientes, México, 2011.

35. Instituto Nacional de Estadística y Geografía (INEGI). Conjunto de Datos Vectoriales de Uso de Suelo y Vegetación Escala 1:250,000; Serie IV (2007-2010); Instituto Nacional de Estadística y Geografía: Aguascalientes, México, 2010. 
36. Instituto Nacional de Estadística y Geografía (INEGI). Banco de Información Económica (BIE); Instituto Nacional de Estadística y Geografía: Aguascalientes, México, 2011.

37. Koutrakis, P.; Wolfson, J.M.; Bunyaviroch, A.; Froehlich, S.E.; Hirano, K.; Mulik, J.D. Measurement of ambient ozone using a nitrite-coated filter. Anal. Chem. 1993, 65, 209-214. [CrossRef]

38. Sedema. Estaciones de Monitoreo. Available online: http:/ /www.aire.df.gob.mx/default.php?opc= $\backslash \mathrm{T} 1 \backslash$ textquoteleftZaBhnmI $=\& d c=\backslash T 1 \backslash$ textquoteleftZA $==$ (accessed on 8 March 2018).

39. Salcedo, D.; Castro, T.; Ruiz-Suárez, L.G.; García-Reynoso, A.; Torres-Jardón, R.; Torres-Jaramillo, A.; Mar-Morales, B.E.; Salcido, A.; Celada, A.T.; Carreón-Sierra, S.; et al. Study of the regional air quality south of Mexico City (Morelos state). Sci. Total Environ. 2012, 414, 417-432. [CrossRef] [PubMed]

40. García-Yee, J.S.; Torres-Jardón, R.; Barrera-Huertas, H.; Castro, T.; Peralta, O.; García, M.; Gutiérrez, W.; Robles, M.; Torres-Jaramillo, A.; Ortínez, A.; et al. Characterization of NOx-Ox relationships during daytime interchange of air masses over a mountain pass in the Mexico City megalopolis. Atmos. Environ. 2018, 177, 100-110. [CrossRef]

41. Barrera-Huertas, H.; Torres, R.; Ruiz-Suárez, L.; Garcia, J.; Gutierrez, W.; Torres, A. Analysis of ozone transportation in Tlaxcala-Puebla Mexico air basin. In AGU Fall Meeting Abstracts; American Geophysical Union: Washington, DC, USA, 2014; p. 3213.

42. Instituto Nacional de Estadística y Geografía (INEGI). Marco Geoestadístico Nacional (MGN) V.5.0.; Instituto Nacional de Estadística y Geografía: Aguascalientes, México, 2010.

43. Hengl, T. A Practical Guide to Geostatistical Mapping of Environmental Variables; JRC Scientific and Technical Reports; Publications Office of the European Union: Luxembourg, 2007; p. 270.

44. Li, J.; Heap, A.D. A Review of Spatial Interpolation Methods for Environmental Scientists; Geoscience Australia: Canberra, Australia, 2008; p. 137.

45. Oficina Estatal de Información para el Desarrollo Rural Sustentable (OEIDRUS). Sistema de Información Geográfica de Morelos; Oficina Estatal de Información para el Desarrollo Rural Sustentable: Cuernavaca, Mexico, 2014.

46. Secretaría de Agricultura, Ganadería, Desarrollo Rural, Pesca y Alimentación (SAGARPA). Servicio de Información Agroalimentaria y Pesquera (SIAP); Secretaría de Agricultura, Ganadería, Desarrollo Rural, Pesca y Alimentación: Ciudad de México, México, 2011.

47. Consejo Nacional de Población (CONAPO). Índice de Marginación por Localidad; Consejo Nacional de Población: Ciudad de México, México, 2012.

48. Grell, G.A.; Emeis, S.; Stockwell, W.R.; Schoenemeyer, T.; Forkel, R.; Michalakes, J.; Knoche, R.; Seidl, W. Application of a multiscale, coupled MM5/chemistry model to the complex terrain of the VOTALP valley campaign. Atmos. Environ. 2000, 34, 1435-1453. [CrossRef]

49. Stockwell, W.R.; Middleton, P.; Chang, J.S.; Tang, X. The second generation regional acid deposition model chemical mechanism for regional air quality modeling. J. Geophys. Res. Atmos. 1990, 95, 16343-16367. [CrossRef]

50. Willmott, C.J. On the validation of models. Phys. Geogr. 1981, 2, 184-194.

51. Song, J.; Lei, W.; Bei, N.; Zavala, M.; De Foy, B.; Volkamer, R.; Cardenas, B.; Zheng, J.; Zhang, R.; Molina, L.T. Ozone response to emission changes: A modeling study during the MCMA-2006/MILAGRO Campaign. Atmos. Chem. Phys. 2010, 10, 3827-3846. [CrossRef]

52. Lei, W.; de Foy, B.; Zavala, M.; Volkamer, R.; Molina, L.T. Characterizing ozone production in the Mexico City metropolitan area: A case study using a chemical transport model. Atmos. Chem. Phys. 2007, 7, 1347-1366. [CrossRef]

53. Jazcilevich, A.; Garcia, A.; Ruiz-Suarez, L. A modeling study of air pollution modulation through land-use change in the valley of Mexico. Atmos. Environ. 2002, 36, 2297-2307. [CrossRef]

54. Escalante García, J.S.; García Reynoso, J.A.; Jazcilevich Diamant, A.; Ruiz-Suárez, L.G. The influence of the Tula, Hidalgo complex on the air quality of the Mexico City Metropolitan Area. Atmósfera 2014, 27, 215-225. [CrossRef]

55. Ruiz Suárez, L.; Longoria, R.; Hernandez, F.; Segura, E.; Trujillo, A.; Conde, C. Emisiones biogénicas de hidrocarburos no-metano y de oxido nítrico en la cuenca del valle de México. Atmosfera 1999, 12, 89-100.

56. Barrera-Huertas, T.-J.R.; Ruíz-Suárez, L.G.; García-Yee, J.S.; Torres-Jaramillo, A.; Martínez, A.P.; Gutierrez, W.; García, L.M.; Robles, M.; Retama, A.; García-Reynoso, J.A. Análisis del transporte de ozono en la cuenca atmosférica de puebla-tlaxcala en el centro de México. Atmosfera 2017. submitted. 
57. Mendoza Flores, A. Análisis de la Calidad del Aire Alrededor del Complejo Industrial en Tula Durante el 2008; Universidad Nacional Autónoma de México (UNAM): Ciudad de México, México, 2011.

58. Granada-Macias, L.M.; Rosas-Perez, R.; Torres-Jardon, R. Ozone levels at a high altitude suburban abies religiosa forest on the western slope of a mountain range under the influence of the Mexico City and Toluca Valley urban areas. Environ. Monit. Assess. 2018. submited.

59. Molina, L.T.; Madronich, S.; Gaffney, J.S.; Apel, E.; de Foy, B.; Fast, J.; Ferrare, R.; Herndon, S.; Jimenez, J.L.; Lamb, B.; et al. An overview of the milagro 2006 campaign: Mexico city emissions and their transport and transformation. Atmos. Chem. Phys. 2010, 10, 8697-8760. [CrossRef]

60. Garcia-Reynoso, A.; Jazcilevich, A.; Ruiz-Suarez, L.G.; Torres-Jardon, R.; Lastra, M.S.; Juarez, N.A.R. Ozone weekend effect analysis in Mexico City. Atmosfera 2009, 22, 281-297.

61. Instituto Nacional de Ecología y Cambio Climático (INECC). Estudios de Calidad del Aire y su Impacto en la Región Centro de México (ECAIM); Instituto Nacional de Ecología y Cambio Climático: Ciudad de México, México, 2014; p. 744.

62. Instituto Nacional de Ecología y Cambio Climático (INECC). Evaluación de las Capacidades Técnicas y de Infraestructura de los Laboratorios Institucionales; Instituto Nacional de Ecología y Cambio Climático: Ciudad de México, Mexico, 2015; p. 25.

63. De Foy, B.; Krotkov, N.A.; Bei, N.; Herndon, S.C.; Huey, L.G.; Martínez, A.-P.; Ruiz-Suárez, L.G.; Word, E.C.; Zavala, M.; Molina, L.T. Hit from both sides: Tracking industrial and volcanic plumes in Mexico City with surface measurements and $\mathrm{OMI} \mathrm{SO}_{2}$ retrievals during the MILAGRO field campaign. Atmos. Chem. Phys. 2009, 9, 9599-9617. [CrossRef]

(c) 2018 by the authors. Licensee MDPI, Basel, Switzerland. This article is an open access article distributed under the terms and conditions of the Creative Commons Attribution (CC BY) license (http://creativecommons.org/licenses/by/4.0/). 